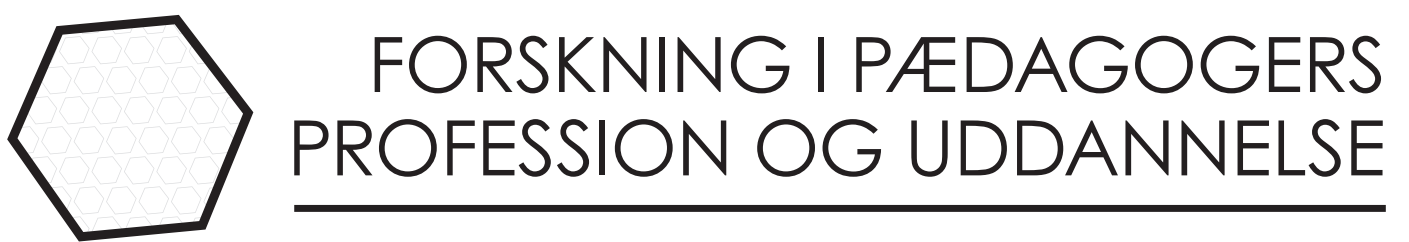

\title{
Computationel tankegang fra et pcedagogisk perspektiv
}

Skolepcedagogens betydning for teknologiinddragelse i matematikundervisningen

\section{Camilla Finsterbach Kaup}

Ph.d.-studerende, Aalborg Universitet og Professionshøjskolen UCN, Lektor på pædagoguddannelsen, UCN

cmf@ucn.dk 


\section{Resumé}

Denne artikel beskriver en undersøgelse af skolepædagogens betydning, når der introduceres til nye digitale teknologier i en undervisningssammenhæng i samarbejde med matematiklæreren. Undersøgelsen belyser, hvordan pædagogen kan være med til at understøtte elevernes tilegnelse af computationel tankegang (CT) som en del af matematikundervisningen. I projektet er der til hver klasse tilknyttet et team bestående af en pædagog og en matematiklærer. Empiriindsamlingen er en del af et ph.d.-projekt med fokus på CT i matematik, hvor der ses på, hvordan klasseteamet kollektivt kan udvikle brugen af CT for at understøtte elevernes matematiske forståelse. I denne artikel indgår der datamateriale i form af observationer fra det pædagogiske personales (pædagog og matematiklærer) undervisning og kompetenceudviklingsproces fra i alt fem 2. klasser fra tre forskellige kommuner. Resultaterne viser, at pædagogen spiller en væsentlig rolle i forhold til at understøtte elevernes internaliseringsproces, når der inddrages nye teknologier i undervisningen, og der er en opfattelse af, at pædagogerne fungerer som et medierende led i elevernes tilegnelse af den computationelle og matematiske forståelse. Det er vigtigt, at pædagogerne kender til de valgte teknologier og selv har afprøvet disse i praksis, da det giver dem større tryghed, når de understøtter både læreren og eleverne i undervisningen.

\section{Abstract \\ Computational thinking from a pedagogical perspective. The social educator's importance for introducing technology in mathematics education.}

This article describes research on the importance of the social educator when new digital technologies are introduced in a teaching context along with the math teacher. It explores how the social educator can facilitate students' acquisition of computational thinking (CT) as part of mathematics. For the project, each class is assigned a team that consists of a social educator and a math teacher. This article is part of a larger project that addresses CT in mathematics, which focuses on how to develop the use of CT to support the students' mathematical understanding. Moreover, this article includes data material such as observations from the teaching and collective professional development process of the pedagogical staff from five second grade classes from three different municipalities. The results reveal that the social educator has a significant role in supporting students' internalization process when new technologies are incorporated into the teaching. The social educator is also considered a mediating element in the students' acquisition of computational and mathematical understanding. It is essential that the social educator is familiar with the selected technologies and has tested them in practice since this experience will increase their confidence in supporting the teacher and the students in the teaching. 
Nøgleord

Computationel tankegang, Digitale artefakter, Understøttende undervisning, Skolepædagog, Teknologiforståelse, Kompetenceudvikling

Keywords

Computational thinking, Digital artefact, Supported teaching, Social educator, Technology understanding, Professional development

\section{Indledning}

Der har den seneste tid været stor uddannelsesmæssig interesse for brugen af digitale artefakter som en del af det teknologiberigende læringsmiljø, hvilket bl.a. ses i forsøgsfaget teknologiforståelse i folkeskolen, hvor eleverne arbejder med at producere digitale artefakter, herunder også i faget matematik (Børneog Undervisningsministeriet, 2020). Der er en generel opfattelse af computational thinking som en tilgang, der kan understøtte og berige disse læringsmiljøer. Begrebet gjorde sit indtog efter Jeanette Wings populære artikel "Computational Thinking" tilbage i 2006. I artiklen sker der et videre arbejde med den danske betegnelse computationel tankegang (CT). Ifølge Wing (2006) er CT en færdighed på højde med det at lære at læse, skrive og regne, CT kan derved betragtes som en kompetence og en analytisk evne, som eleverne bør opnå for at kunne klare sig i nutidens samfund. Arbejdet med CT er også medvirkende til, at eleverne kan tilegne sig computational empowerment. Dette fordrer, at eleverne er skabende, nysgerrige og kritiske i henhold til teknologien og opnår en evne til at forstå den påvirkning, der udøves af digitale artefakter i hverdagen (Iversen et al., 2018).

På tværs af litteraturen anses CT som en problemløsningsstrategi, og den er ofte defineret igennem underbegreber og tankeprocesser. Ifølge Grover \& Pea (2018) er kerneelementerne logik, algoritmer, abstraktion, mønstergenkendelse, evaluering og automation. De definerer desuden computationelle praksisser som dekomposition, skabelse af computationelle artefakter, testning, fejlsøgning og iterative processer. I denne artikel anses problemløsning for at tilhøre en kontekst, hvor eleverne kan opleve og udvikle deres matematiske forståelse ved hjælp af begreberne fra CT, og der sker en udforskning af, hvordan pædagogen kan være med til at understøtte disse processer igennem computationel deltagelse. Kafai \& Burke (2016) beskriver computationel deltagelse som en social vending, hvor de ser et skifte i fokusset på teknologi. Det er ikke blot teknologien, der her er under lup, men også de bagvedliggende tankeprocesser og det at være skabende i et fællesskab, som de fremhæver som væsentlige aspekter. Computationel deltagelse handler om at deltage i sociale netværk, hvor det er muligt igennem et fællesskab at arbejde algoritmisk med problemløsning. 
Denne artikel bygger på et igangværende ph.d.-projekt, der overordnet set belyser, hvordan pædagoger og matematiklærere kan arbejde med at skabe effektive strategier ved at inddrage CT i matematikundervisningen, og hvordan dette kan være med til at understøtte elevernes matematiske forståelse. Ved at se på CT i et sociokulturelt perspektiv fremhæves klassens interaktioner, brugen af sproget og artefakter såvel som kognitive strategier, der kan støtte eleverne i deres tilegnelse af CT. Det handler ikke så meget om teknologien, men om en måde, hvorpå eleverne kan blive støttet i deres tankeproces og bruge denne strategi til at hjælpe dem med at forstå matematiske begreber. Der arbejdes ud fra en forståelse af, at kerneelementerne fra CT kan hjælpe eleverne med at skabe mening ud fra matematiske begreber ved at gøre tænkningen transparent igennem brugen af forskellige repræsentationsformer (Kynigos \& Grizioti 2018). Det er igennem denne bearbejdelse, at arbejdet med CT gradvist vil være med til at styrke elevernes computationelle empowerment (Iversen et al. 2018).

\section{Forskningsspørgsmål og prcemis}

CT er blevet en central del i mange læringsdiskussioner og er efterhånden skrevet eller på vej til at blive skrevet ind i mange landes læreplaner (Bocconi et al., 2015). Nationalt er forskningen i forhold til CT i sin spæde start, men danske 8. klasseelevers computationelle tænkning er dog blevet testet som en del af den internationale test ICILS i 2018. I sammenligning med de 11 andre deltagende lande opnåede de danske elever i henhold til CT en samlet andenplads. Ifølge Jeppe Bundsgaard, Sofie Gry Binderslev, Elisa Nadire Caeli, Morten Pettersson \& Anna Rusmann (2019) er det interessant, at danske elever klarer sig så flot, idet det er de færreste elever, der tidligere har arbejdet kontinuerligt med computationelle aktiviteter. Der findes derfor ikke belæg for at vide, om resultatet kan forklares med baggrund i skolen eller det omkringliggende samfund i forhold til at ruste eleverne med computationelle kompetencer. I Danmark er man i gang med et forsøg omkring teknologiforståelse i folkeskolen (2019-2021), og et af de kompetenceområder, der testes, er CT. I midtvejsevalueringen fremkom det, at det kompetenceområde, eleverne og det pædagogiske personale har sværest ved, er CT. Dette kan skyldes, at det pædagogiske personale selv finder det vanskeligt at italesætte og skabe forståelse for kompetenceområdet CT (Børne- og Undervisningsministeriet, 2020). Der mangler således fortsat viden om, hvordan uddannelsessektoren kvalificeret kan arbejde med CT i forbindelse med at understøtte elevernes tilegnelse af computationelle kompetencer, og i særdeleshed hvordan pædagogerne kan være med til at understøtte arbejdet med CT.

Med skolereformen i 2014, ændredes pædagogens rolle i skolen, og pædagogen fik en væsentlig større rolle i løbet af skoledagen. Pædagogerne skulle udover fritidspædagogikken nu også forholde sig til didaktik og læring i samarbejde med lærerne. Siden reformen har samarbejdet mellem pædagoger og lærere været et centralt tema indenfor forskning (Gravesen \& Ringskou, 2016; Jacobsen et al., 
2020). Denne artikel tager udgangspunkt i en fælles udviklingsproces mellem lærere og pædagoger, men vil have sit fokus på, hvordan pædagoger kan understøtte elever, når CT inddrages i matematikundervisningen. Artiklen vil ligeledes belyse, hvilken rolle pædagoger får, når nye teknologier inddrages i undervisningen. Det centrale bliver således at skabe en forståelse omkring pædagogens rolle, når eleverne arbejder med $\mathrm{CT}$ i matematikundervisningen. Udviklingsprocessen skal ses som værende formativ, hvor det pædagogiske personale arbejder med at bearbejde eksempler fra egen praksis, for derigennem at udvikle nye handlingsforslag til brug i undervisningen.

Læringsperspektivet i artiklen bygger på Lev S. Vygotskys (1978) læringsforståelse, hvor læring er en måde, hvor der sker en påvirkning af elevens individuelle, sociale og kontekstuelle sammenhænge. Ud fra dette perspektiv er mennesker sociale og refleksive, hvilket bevirker, at menneskets tanker og adfærd er påvirket af den kompleksitet, den sociale verden er indlejret i. Særligt i denne artikel vil der være fokus på at se på læring som en medieret proces, der er organiseret igennem digitale artefakter, aktiviteter og begreber. I denne artikel vil jeg undersøge følgende forskningsspørgsmål: Hvilken betydning har det, at pædagogerne deltager i en kollektiv faglig udviklingsproces, når de skal være med til at understøtte elevernes internaliseringsproces i arbejdet med CT i matematikundervisningen?

\section{Medieret laring}

Virksomhedsteorien har sit udspring i den russiske psykologi (Engeström, 2011). Lev Vygotsky udviklede den oprindeligt mellem 1920 og 1930, og den var centreret omkring hans interesse for medierede forestillinger om menneskers højere mentale tækning. Forholdet mellem mennesker og dets omgivelser vil, ifølge Vygotsky (1978), altid være medieret igennem kulturelle betydninger som tegn og artefakter, der igennem tiden er udviklet af mennesket. Det medierede er i denne sammenhæng, at man skaber og gør al praksis mulig igennem en række konceptuelle og materielle genstande, fx digitale artefakter og redskaber, som stammer fra vores kulturelle arv eller sociale miljø. Ifølge Vygotsky (1978) spiller sproget en væsentlig rolle i denne mediering, hvor medieringen flytter sig fra et udvendigt til et indvendigt plan ved hjælp af internalisering. Internalisering beskriver den proces, hvorpå individet rekonstruerer en ydre påvirkning til en indre forståelse, som derigennem bliver en del af de højere mentale funktioner. Sproget fremtræder således to gange hos eleven først som en ydre og dernæst som en indre forklaring. Igennem deltagelse i aktiviteter med andre mennesker vil elever internalisere sproget, teorier, normer og måder at agere på i kulturelle sammenhænge. Det er handlingen og derigennem anvendelsen af redskaber, i dette tilfælde digitale artefakter, der har betydning for elevens udvikling (Dale, 2006). For at kunne forklare elevens deltagelse er fremgangsmåden at søge forklaringer i de omkringliggende sociale interaktioner for at kunne skabe forståelse for de pågældende processer og de handlinger, der ligger bag. Derfor vil der være 
fokus på pædagogens rolle i denne (tilegnelses)proces. Særligt den sociale og kulturelle kontekst er introduceret i Vygotskys nøglebegreber: Zonen for nærmeste udvikling og internalisering. Zonen for nærmeste udvikling (NUZO) beskriver en læreproces, der sker via social interaktion. NUZO er af Vygotsky defineret som den afstand, der er mellem det aktuelle og det potentielle udviklingsniveau, hvor den potentielle udvikling fungerer som problemløsning gennem guidning af en voksen eller anden mere erfaren lærerende $(1978$, s. 86). Det interessante i en pædagogisk sammenhæng er således, hvordan pædagogerne i en faglig kontekst kan være med til at understøtte denne internaliseringsproces igennem elevernes NUZO.

\section{Det digitale artefakt}

Igennem tiden har mennesket udviklet både materielle og psykologiske artefakter, som ved hjælp af mediering kan hjælpe os med at forstå vores omverden. I et kulturhistorisk perspektiv har artefakterne indlejret generationsindsigter og erfaringer, som kommer til udtryk igennem mediering (Vygtosky, 1978). I dette perspektiv anser man også digitale teknologier som et materielt artefakt med en indlejret intentionalitet, idet det er en materiel genstand, der er frembragt med et bestemt formål, og der sker igen en re-konfigurering ved brug af det i en social kontekst (Hasse et al., 2015). Artefakterne medierer eller formidler læring på mange måder, alt efter i hvilken kontekst der sker en inddragelse af dem. Ved at arbejde ud fra Vygotskys (1978) læringsforståelse bliver det således muligt at arbejde med en udviklingsdimension, hvor artefakter er et vigtigt element i læreprocessen. Samtidig kan hans læringsforståelse danne teoriramme i studiet af brugen af digitale artefakter indenfor uddannelsessektoren. Her bliver det muligt at betragte robotter som medierende digitale artefakter med indlejrede computationelle egenskaber, der gør det muligt for eleverne at arbejde med deres computationelle tænkning.

\section{Metode}

Til at udfolde det pædagogiske personales udviklingsforløb vil jeg anvende Vygotskys princip om dobbelt stimulation, som ifølge Engeström (2011) kan fremkalde nye handlemuligheder blandt deltagerne. Det pædagogiske personale blev præsenteret for en problemstilling eller en undervisningsaktivitet fra egen praksis (første stimulus) og fik derefter en guidning af forskeren (anden stimulus) til at skabe nye handlemuligheder i praksis. Under indsamlingen af første stimulus anvendte jeg et kvalitativt perspektiv, hvor der indgik observationer, ud fra et ønske om at se på deltagernes interaktioner mellem det materielle og sociale miljø for at forstå, belyse og undersøge det pædagogiske personales rolle (Brinkmann \& Tanggaard, 2010). Herefter fulgte min anvendelse af deltagerobservation med et perifert medlemskab, hvilket muliggjorde skabelsen af en insiders identitet, 
uden at dette gik ud over kernen i klasserumsaktiviteterne. Dette gav mulighed for både at komme tættere på under observationerne for at se, hvordan eleverne udførte opgaverne på klassen, men også hvordan det pædagogiske personale understøttede disse aktiviteter. Til at understøtte observationerne benyttede jeg feltnoter og videoobservation med stationært kamera, hvis formål var at indfange mere generelle informationer fra det pædagogiske personale til eleverne i klassen (Kawulich, 2005).

Dette gjorde det muligt at skabe en vekslen mellem aktiviteter i klasserummet, hvor det pædagogiske personale arbejdede med CT og matematik, samt udviklingssessioner, hvor det pædagogiske personale kunne reflektere over og analysere deres egen praksis. Jeg foretog observationerne løbende for at skabe indsigt i, hvordan arbejdet med de digitale artefakter fandt sted, og hvordan tilvejebringelse af dette fungerede i praksis. Ved at være til stede som forsker får man en dybere forståelse for situationen og de elementer, der indgår i selve undervisningskonteksten. Denne viden bruger man til at understøtte det pædagogiske personale i deres udviklingsproces (Engeström, 2011). Under udviklingssessionerne planlagde det pædagogiske personale en ny intervention for at redefinere deres forståelse og afprøve nye tiltag i klasserummet, og processen fortsatte derefter.

De deltagende skoler er fundet med hjælp fra skoleforvaltningerne i de respektive kommuner. Det deltagende pædagogiske personale har dernæst tilkendegivet, om de ønskede at deltage i ph.d.-projektet. Deltagerne havde ingen eller kun lidt erfaring med at arbejde med digitale artefakter og CT i en undervisningssammenhæng. I det samlede ph.d.-projekt deltog i alt fire skoler; i denne artikel vil fokus være på de tre af skolerne, da den fjerde skole ikke deltog med deres skolepædagoger. Skole nr. 1 og 2 deltog begge med en klasse og ét klasseteam, skole nr. 3 deltog med tre klasser og tre klasseteams, hvert klasseteam bestod af en matematiklærer og en pædagog. Denne artikel er blevet til på baggrund af to observationer i hver klasse; hver observation blev efterfulgt af en udviklingssession med det pædagogiske personale. Videooptagelserne og deltagelsen i klasseobservationerne blev optaget med tilladelse fra det pædagogiske personale og elevernes forældre. Jeg behandlede efterfølgende dataene fortroligt og anonymiserede deltagerne. Alle skoler arbejdede under disse observationer med robotten Bee-Bot, så det digitale artefakt, der lå til grund for undersøgelsen, har dermed været den samme.

\section{Tematisk analyse}

Jeg vil i det følgende kort redegøre for de beslutninger, jeg traf igennem analyseprocessen. Dette er sket via Braun \& Clarkes (2006) seks trin for tematisk analyse. Disse trin er følgende: Bliv kendt med data, generér indledende koder, søg efter temaer, evaluér dem; definér dem og producér det skriftlige arbejde. Da den tematiske analyse indgår som en del af et udviklingsforløb, skal den ses som en iterativ proces, hvor flere af trinnene vil blive gennemløbet flere gange. 
For at reflektere over dataindsamlingen skrev jeg mine umiddelbare refleksioner ned efter hver observation og udviklingssession med praksis. De efterfølgende renskrivninger af observationsnotaterne og refleksionerne var med til at give indblik i datamaterialet. Observationsnotaterne var det bindende led i forhold til at finde første stimulus til udviklingssessionerne. De blev påført med tidsnotater, så det var muligt at tilgå videomaterialet for yderligere at udfolde forståelsen af observationerne og indsamle artefakter til brug som spejlingsmateriale af det pædagogiske personale (Engeström, 2011). Den indledende kodning startede efterfølgende, hvor meningskoder blev brugt til at give overblik og skabe struktur over datamaterialet (Braun \& Clarke, 2006). Her foregik der en meningskondensering, hvor meningen i sætningen eller i et observationsnotat blev kodet. Dette foregik i første omgang særskilt for den enkelte skole, da skolerne er forskellige steder i deres udviklingsproces. Det første datasæt for hver skole blev kodet og grupperet, og hvert efterfølgende datasæt analyserede jeg og sammenlignede dernæst med de data, der tidligere var analyseret. I denne proces blev mønstre identificeret og placeret ved tilsvarende mønstre fra tidligere analyserede data, så der ved indsamling af data kunne foretages en sammenligning mellem datasættene for hver enkelt skole. I løbet af denne proces gennemgik jeg mønstrene og grupperede dem sammen med relaterede mønstre til overordnede temaer (Percy et al., 2015). Derefter søgte jeg efter temaer, som skulle indgå som spejling af første stimulus i udviklingsforløbet, og jeg evaluerede og videreudviklede derefter temaerne i samarbejde med praksis. Dette muliggjorde også, at nye temaer kunne dukke op, og forståelsen for de valgte temaer blev nuanceret i processen.

Forud for denne artikel genbesøgte jeg temaerne fra hver enkelt skole og så på nye grupperinger og nye overordnede temaer, som relaterer sig til forskningsspørgsmålet og pædagogernes praksis. For at besvare denne artikels forskningsspørgsmål er det temaerne teknologi og understøttelse, der vil være i fokus.

\section{Understøttelse af $\mathrm{CT}$ igennem mediering}

Temaet understøttelse omhandler, hvordan pædagogerne igennem deres tilstedeværelse kan understøtte lærerne i arbejdet med robotterne i undervisningen. Igennem den tematiske analyse fremkom det, at pædagogerne havde en understøttende rolle i henhold til at inddrage robotterne i undervisningen. Set ud fra observationerne spiller pædagogen en væsentlig rolle ved introduktion af opgaverne, særligt på den tredje skole, hvor der i alt deltog tre klasseteams. Her var pædagogerne med til at skabe de materialer, der skulle bruges i forbindelse med undervisningen. De tre klasseteams havde sammen udviklet plader af pap, hvor der var tegnet kvadratiske felter ind, hvorpå robotten kunne køre. De enkelte opgaver som blev brugt ved inddragelse af robotten i undervisningen, havde de også udviklet i fællesskab. Pædagogerne havde været med til at udvikle materialerne og havde selv afprøvet robotterne, hvilket gjorde, at de kunne sætte sig selv mere i spil i undervisningen. Dette illustrerer følgende eksempel: 


\begin{abstract}
"Pappladen ligger på gulvet, og eleverne står $i$ rundkreds rundt om loereren og pcedagogen, der begge sidder på gulvet. Pcedagogen får til opgave af loereren at programmere robotten til at gå hen på tallet 15. Pcedagogen fortceller, hvad han trykker ind på robotten: "tre pile frem og en til venstre og igen en pil frem", og han stiller spørgsmålet til eleverne: "så kommer den hen på tallet 15, gør den ikke?". Hertil svarer et par elever nej, men de bliver alligevel enige om, at pæedagogen skal trykke på GO, så robotten sctter i bevœgelse. Robotten lander ikke på tallet 15, da den $i$ stedet for at gå til venstre skulle have voeret drejet til højre. Herefter får en af eleverne lov til at programmere robotten hen på tallet 15". (Observation, skole nr. 3b).
\end{abstract}

Eksemplet viser, at pædagogen brugte robotten som medierende artefakt, og han italesatte og demonstrerede, hvad han gjorde. Pædagogen viste også eleverne, at det er ok at tage fejl og prøve forfra undervejs i arbejdsprocessen. Pædagogen understøttede således læreren under introduktionen af opgaven, men kunne også understøtte og legimitere de udfordringer, eleverne arbejder med undervejs. Igennem denne introduktion og undervejs i undervisningen var pædagogen med til at understøtte elevernes NUZO, da eleverne bevægede sig fra at udføre opgaver kollektivt på klassen til at udføre dem i mindre grupper efterfølgende. Dette sker igennem det Vygotsky (1978) kalder imitation. I ovenstående eksempel viser pædagogen eleverne, hvordan de kan arbejde med robotten. Efterfølgende arbejder eleverne selv med det der blev vist, hvilket således er med til at understøtte eleverne i arbejde inden for deres NUZO.

\begin{abstract}
"På skole nr. 3 re-designede to grupper den opgave, de havde fået stillet. Eleverne skulle ved hjoelp af tallene på pappladen stille hinanden regnestykker og programmere robotten hen på resultatet. Efter et stykke tid valgte den ene gruppe at skubbe deres papplade over til en anden gruppe, og eleverne havde nu dobbelt råderum i forhold til at lave regnestykker, men også større handlerum for robotten. Dette blev observeret af pcedagogen, der kom hen og anerkendte, at de havde bygget videre på opgaven”. (Observation, skole $n r .3 b)$.
\end{abstract}

Eksemplet her blev brugt som spejlingsmateriale i den efterfølgende udviklingssession for at illustrere, at eleverne re-designede den stillede opgave. Det er også et eksempel på, at eleverne har brug for at blive udfordret i deres læringsaktiviteter for fortsat at være i NUZO. Eleverne i eksemplet demonstrerer, at de er nået et sted i deres udviklingszone, hvor de godt selv kan. De har derved brug for nye udfordringer for at blive indenfor deres NUZO. På udviklingssessionen kunne pædagogen godt huske episoden, og der blev åbnet op for en diskussion om det at differentiere opgaverne. Her var der enighed om, at grupperne ikke nødvendigvis behøvede at få en ny opgave stillet på sammen tid. Dog fandt det pædagogiske personale det også vigtigt, at der fortsat skulle være plads til, at eleverne kunne re-designe de stillede opgaver og på den måde selv være med til at regulere deres læring. Fremadrettet ville det pædagogiske personale sikre sig større mulighed for at kunne variere opgaverne imellem grupperne og skabe rum for, at eleverne kunne re-designe og udvikle opgaverne yderligere. I den forbindelse blev det fremhævet, at det fortsat var vigtigt, at pædagogen også kendte til de enkelte opgaver, 
så han/hun kunne give en ny opgave videre til grupperne uden først at skulle omkring læreren.

Det var vigtigt, at pædagogerne deltog sammen med lærerne, når det gjaldt om at afprøve og udvikle opgaver til brug i undervisningen, da det gav mulighed for ikke kun at arbejde med elevernes matematiske forståelse, men også elevernes potentielle udfordringer. Ved at pædagogerne på skole nr. 3 var med til at udvikle opgaverne til brug i undervisningen, bidrog det til at pædagogerne kunne hjælpe eleverne i deres internaliseringsproces af de matematiske begreber, da de kendte strukturerne og det didaktiske indhold.

\title{
Understøttelse af eleverne trods mangel på falles forberedelse
}

I ph.d.-projektet fremkommer det ligeledes, at det ikke altid var muligt at finde tid til den fælles forberedelse lærere og pædagoger imellem på alle skoler. Pædagogen i nedenstående eksempel kendte ikke til timens indhold, hvilket gjorde, at det blev svært at understøtte lærerens faglige intentioner. Pædagogen understøttede i stedet elevernes initiativ i deres computationelle arbejde med robotten. Dette bevidner følgende observationsnotat også:

\begin{abstract}
"En gruppe elever begyndte at finde nogle trcpinde frem, som stod $i$ en kasse $i$ et hjørne af rummet og begyndte at bygge en labyrint til robotten. Poedagogen satte sig sammen med dem, og yderligere to grupper kom hen og fandt trœpinde og begyndte at bygge labyrinter. Dette var ikke en del af de opgaver, der var blevet stillet på klassen. Pcedagogen kendte ikke til de opgaver, eleverne fik stillet af loereren, og fulgte derfor elevernes initiativ og var undersøgende sammen med dem. Eleverne fik lektionen igennem lov til at udbygge og prøve sig frem med robotterne i labyrinterne. Podagogen blev siddende ved disse grupper lektionen igennem. I starten var han undersøgende med eleverne i forhold til, hvad robotten kunne, og stillede undrende spørgsmål". Fx: "Hvad sker der, hvis jeg ikke trykker på kryds og trykker en ny kode ind?". (Observation, skole nr. 2).
\end{abstract}

Spørgsmålene var med til at gøre, at eleverne forholdt sig forklarende til det digitale artefakt og blev støttet i deres internaliseringsproces. Internaliseringsprocessen blev skabt ved, at eleverne reflekterede over spørgsmålene, som blev besvaret eller demonstreret via robotten. Robotten fungerede derved også som medierende artefakt for elevernes efterfølgende besvarelse af spørgsmålene (Vygotsky, 1978). Det var også igennem denne internaliseringsproces, at pædagogen understøttede elevernes computationelle praksis ved at udfordre dem med spørgsmål, der gjorde, at de både arbejdede med abstraktion og med mønstergenkendelse. Sproget og herunder de tegn på en begyndende computationel forståelse fremstår derved som centralt for elevernes internaliseringsproces. Pædagogen blev igennem lektionen siddende med disse tre grupper, hvilket gjorde, at han kunne variere sine spørgsmål til de enkelte grupper. Fx fik den ene gruppe til opgave at programmere robotten fra den ene ende af labyrinten til den anden via én algoritme, hvor de før delte labyrinten op i små dele. En anden gruppe blev spurgt ind til, hvordan de kunne bygge labyrinten, så gangene ville passe med den længde, robotten gik (robotten 
flytter sig $15 \mathrm{~cm}$, hver gang den går et tryk frem). På den måde kunne pædagogen tilpasse de opgaver, han stillede, så de passede til elevernes NUZO og samtidig være med til at styrke deres internaliseringsproces ved at gå i dialog med dem. Det viste sig at være centralt, at pædagogen forholdt sig undrende og spørgende overfor det digitale artefakt på denne måde. De undrende og åbne spørgsmål var med til at understøtte eleverne i at være problemløsende og sørge for de forsat var indenfor NUZO. Pædagogen blev dermed et medierende led i forhold til elevernes arbejde med robotten. I starten ville det være robotten, der ansås som et objekt, eleverne arbejdede på at forstå, og her vil pædagogens rolle blive helt central i forhold til at understøtte eleverne ved at bruge sproget som medierende artefakt gennem at stille spørgsmål og være undersøgende sammen med eleverne. Det centrale i dette eksempel er, at eleverne opnåede en høj grad af computationel forståelse, og eleverne fik her en god forståelse for, hvordan robotten virkede via støtte fra pædagogen. Der mangler dog her en kobling til det matematikfaglige område, og elevernes handlinger blev derved ikke koblet til deres matematiske forståelse.

På den efterfølgende udviklingssession blev der spurgt ind til undervisningsgangen, og læreren nævnte, at de opgaver, der blev stillet, måske havde været for abstrakte for eleverne at gå i gang med uden støtte. Det var også en erkendelse af, at der ikke havde været tid til at forberede pædagogen forud for undervisningen, hvilket gav et andet perspektiv på undervisningen, hvor der blev plads til at følge elevernes initiativer. Det var derfor en generel opfattelse, at det var et godt tiltag, at pædagogen i dette tilfælde havde fulgt børnenes initiativ og var med til at udfolde deres forståelse og mediering med robotterne. Eksemplet viser også, at når pædagogen ikke kender til det matematikfaglige indhold, er det svært at understøtte dette, og det matematiske bliver derved ikke omdrejningspunktet i de handlinger, pædagogen er en del af.

\section{Teknologi i undervisningen}

Det pædagogiske personale oplevede, at når de arbejdede med brugen af digitale artefakter i undervisningen, så havde de et behov for at kende det digitale artefakt rigtig godt. Når de selv arbejdede og afprøvede robotten, kunne de i højere grad selv udvikle nye opgaver til brug i undervisningen og følte sig mere sikre, når de skulle introducere det for klasserne. Forberedelse fremtræder derfor også som et centralt element ved arbejdet med digitale artefakter i undervisningen, da det ellers til tider er svært både at favne både CT og den matematiske forståelse. Under udarbejdelsen af undervisningsmaterialerne fremkom det, at robotten ikke kunne anses som et artefakt, der kunne mediere og udvikle elevernes matematiske forståelse, men at det var brugen af robotten ud fra en didaktisk rammesætning, der skabte mulighederne for at kunne understøtte den matematiske begrebsforståelse.

Det pædagogiske personales deltagelse i de fælles udviklingssessioner gjorde, at de sammen kunne oparbejde et nyt fællessprog omkring arbejdet med CT og 
matematik og sammen understøtte den nye faglighed. Igennem de fælles udviklingssessioner arbejde det pædagogiske personale således med deres egen internaliseringsproces og derigennem deres egen forståelse af CT. Gældende for de tre deltagende skoler var det robotten og matematikken, der var fremtrædende, og eleverne arbejdede med CT gennem robottens indlejrede computationelle egenskaber. Det er således først i de efterfølgende sessioner, at det pædagogiske personale blev opmærksomme på, hvilken grad af CT eleverne arbejdede med under udførslen af de opgaver det pædagogiske personale havde udviklet til undervisningen. CT var ikke tænkt ind i opgaverne, men ved at arbejde med robotterne understøttede det pædagogiske personale elevernes CT. Dog var det ofte igennem dialog enten i opsamling på klassen eller i de små grupper, at de computationelle begreber blev bragt i spil. Her er det vigtigt, at pædagogen ikke blot indtager en observerende rolle, men går i dialog med eleverne og er med til at understøtte deres internaliseringsproces både i henhold til CT, men også i henhold til elevernes matematiske forståelse.

Særligt på skole nr. 3 havde pædagogerne en væsentlig rolle at spille, når en ny opgave blev introduceret i klassen. Her gik de i dialog med lærerne og var med til at stille spørgsmål og være undrende sammen med eleverne i forhold til robotten.

\begin{abstract}
"I b-klassen byttede loereren og pcedagogen roller, da en ny opgave skulle introduceres, hvilket ikke var aftalt på forhånd, men fremkom helt naturligt (observation, skole nr. 3b). I den efterfølgende udviklingssession kom dette klasseteam også frem til, at det ikke nødvendigvis altid behøvede at voere matematiklcereren, der introducerede til nye opgaver eller ny teknologi. Det fremkom, at det lige så godt kunne vcere pcedagogen, som havde andre teknologiske kompetencer end matematikloereren og derved kunne lave introduktionen til nye teknologier. Dette er et af de tiltag, dette klasseteam vil scette fokus på fremadrettet". (Udviklingssession nr. 2, skole nr. 3).
\end{abstract}

Det fremkom på skole nr. 3, at det ene klasseteam særligt understøttede hinanden godt, og at de godt kunne gå væk fra den mere traditionelle form for undervisning, hvor matematiklæreren formidler den faglige viden, og pædagogen udelukkende understøtter den faglige undervisning. Ovenstående illustrerer også, at pædagogen i form af sine kompetencer bedre kunne understøtte elevernes computationelle internaliseringsproces. Pædagogen benyttede et mere computationelt sprogbrug ved introduktionen af den matematiske opgave, hvor eleverne eksempelvis skulle lave en algoritme og de tilhørende koder skulle skrives ned som en del af løsningen. Pædagogen gør således brug af både matematiske- og computationelle begreber, og er på den måde med til at understøtte elevernes begyndende internaliseringsproces, ved at sprogliggøre begreberne og sætte det ind i en matematisk kontekst.

\title{
Konklusion og perspektivering
}

I denne artikel har jeg med udgangspunkt i CT set på pædagogens rolle, når nye digitale artefakter inddrages i matematikundervisningen. Det fremkom, at det 
havde betydning for pædagogerne, at de arbejdede med digitale artefakter igennem et kollektivt udviklingsforløb. Dette forløb var med til at klæde pædagogerne på til at kunne understøtte lærerne og eleverne i undervisningen og gjorde at pædagogerne kunne arbejde med deres egen internaliseringsproces i henhold til at skabe en forståelse for CT. Det fremkom tillige, at pædagogen får en central rolle at spille i arbejdet med de digitale artefakter i klasserummet. Her er pædagogerne på de deltagende skoler, via deres handlinger og brug af sproget, med til langsomt at stimulere elevernes internaliseringsproces. Ved at stille undrende og åbne spørgsmål til eleverne er de med til at sikre, at eleverne i videst muligt omfang befinder sig i NUZO. Det er også igennem sproget og internaliseringsprocessen, at pædagogerne kan være med til at understøtte eleverne i deres computationelle- og matematiske forståelse. Ved at arbejde med robotten bliver eleverne, pga. dens indlejrede computationelle egenskaber, udfordret af pædagogerne til at undersøge robottens computationelle praksisser. Pædagogerne er således med til at understøtte elevernes tilegnelse af redskaber, der på sigt kan hjælpe dem med at løse komplekse problemstillinger ved hjælp af computationelle tankeprocesser. Konklusionen er, at ved introduktionen af nye digitale artefakter er pædagogerne ikke nødvendigvis kun med til at understøtte elevernes handlinger, men er i høj grad også med til at forme interaktionen i aktiviteten samt de roller, elever og pædagoger får mulighed for at indtage.

Computationel tankegang er som begreb ved at skrive sig ind i en dansk kontekst, men som jeg skitserede i indledningen, mangler der fortsat viden om, hvordan CT bedst kan introduceres i undervisningssammenhænge. Dette projekt arbejder med det udgangspunkt, at CT ses som en del af den faglige undervisning, og kigger også på, hvordan forskellige professionsbaggrunde kan være med til at berige undervisningen. Undersøgelsen illustrerer, at pædagogerne kunne være med til at forme undervisningen ved at byde ind med deres kompetencer. Fremadrettet ses der dermed potentiale i, at pædagogerne også inddrages i forberedelsen af det faglige indhold for på den måde bedst at kunne støtte eleverne i deres internaliseringsproces. Det kollektive samarbejde bliver i særdeleshed væsentligt, når et nyt begreb som CT tilføres undervisningen.

\section{Litteratur}

Ananiadou, K., \& Claro, M. (2009). 21st century skills and competences for new millennium learners in OECD countries. OECD Education Working Papers, 41. OECD Publishing.

Bocconi, S., Chioccariello, A., Dettori, G., Ferrari, A., Engelhardt, K. (2016). Developing

computational thinking in compulsory education - Implications for policy and practice, http:// dx.doi.org/10.2791/792158

Brinkmann, S., \& Tanggaard, L. (2010). Kvalitative metoder: en grundbog. Hans

Reitzel.

Braun, V., \& Clarke, V. (2006). Using Thematic Analysis in Psychology in Qualitative Research in Psychology 3(2), 77-101. https://doi.org/10.1191/1478088706qp063oa 
Børne- og Ungeministeriet (2020). Midtvejseveluering forsøg med Teknologiforståelse $i$ Folkeskolens obligatoriske fag, rapport, https://emu.dk/grundskole/forskning-og-viden/paedagogisk-it/ forste-erfaringer-fra-forsog-med-teknologiforstaelse-i

Dale, L.A. (2006). Læring og udvikling, in Bråten, I. (red) leg og loering $i$ Vygotsky i poedagogikken (pp. 47-82) Frydenlund.

Bundsgaard, J., Binderslev, S., Caeli, E., Pettersson, M., \& Rusmann, A. (2019). Danske elevers teknologiforståelse - Resultater fra ICILS-undersøgelsen. Aarhus Universitetsforlag.

Engeström, Y. (2011). From design experiments to formative interventions. Theory \& Psychology, 21(5), 598 - 628. https://doi.org/10.1177/0959354311419252

Folkeskoleloven (2017). Bekendtgørelse af lov om folkeskolen (LBK nr. 823 af 15/08/2019). https:// www.retsinformation.dk/eli/lta/2019/823

Gravesen, D.T. og Ringskou, L. (2016). Rum for kvalifikation, plads til inklusion? - om mødet mellem børn, rum og pædagogik i den danske folkeskole. Nordisk tidsskrift for pedagogikk og kritikk, Vol. 2, 47-63. http://dx.doi.org/10.17585/ntpk.v2.275

Grover, S. \& Pea, R. (2018). Computational thinking: A competency whose time has come. In Sentance, S., Carsten, S., \& Barendsen, E. (Eds). Computer Science Education: Perspectives on Teaching and Learning (pp. 269-288), Bloomsbury.

Hasse, C., Wallace, J., Brok, L. S., Gars Jensen, U., Skov, H., Schrøder, V., \& Dupret, K. (2015). TEKU-modellen: Teknologiforståelse i professionerne. U Press.

Iversen, O.,S., Smith, R. C., \& Dindler, C. (2018). From Computational Thinking to Computational Empowerment: A 21st Century PD Agenda. In PDC '18: Proceedings of the 15th Participatory Design Conference - Vol. 1, https://doi.org/10.1145/3210586.3210592

Jacobsen, G., Larsen, D., \& Nielsen, O. (2020). Arrangementet som pædagogisk handlingsform. Forskning I Pcedagogers Profession Og Uddannelse, 4(1), 34-46. https://doi.org/10.7146/fppu. v4i1.119213

Kafai, Y.B. \& Burke, Q. (2016). Connected code - why children need to learn programming. The MIT Press.

Kawulich, B.B. (2005). Participant Observation as a Data Collection Method. Qualitative Social Research, Volume 6, No. 2, Art. 43

Kynigos, C., \& Grizioti, M. (2018). Programming Approaches to Computational Thinking: Integrating Turtle Geometry, Dynamic Manipulation and 3D Space. Informatics Education, 17, 321-340 https://doi.org/10.15388/infedu.2018.17

Vygotsky, L.S. (1978). Mind in society - the development of higher psychological processes. Red. Cole, M., John-Steiner, V., Scribner, S. \& Soubermann, E. Harvard University Press.

Wing, J. M. (2006). Computational thinking. Communications of the ACM, 49(3), 33-35. 